\title{
Reviving the Coordination Chemistry of Sulfonium Cations
}

\author{
Ruiping Li, Nitsan Barel, Vasudevan Subramaniyan, Orit Cohen, Françoise Tibika, and Yuri \\ Tulchinsky*
}

Institute of Chemistry, The Hebrew University of Jerusalem, Jerusalem, 9190401, Israel;

e-mail: yuri.tulchinsky@mail.huji.ac.il

KEYWORDS: sulfonium ions, cationic ligands, $\pi$-acceptor ligands, $\pi$-acid catalysis, main group chemistry.

\begin{abstract}
More than a century old, sulfonium ions are still intriguing species in the landscape of organic chemistry. On one hand they have found broad applications in organic synthesis and material science, but on the other hand, while isoelectronic to the ubiquitous tertiary phosphine ligands, their own coordination chemistry has been neglected for the last three decades. Here we report the synthesis and full characterization of the first $\mathrm{Rh}(\mathrm{I})$ and $\mathrm{Pt}(\mathrm{II})$ complexes of sulfonium. Moreover, for the first time, coordination of an aromatic sulfonium has been established. A thorough computational analysis of the exceptionally short S-Rh bonds obtained attests for the strongly $\pi$-accepting nature of sulfonium cations and places them among the best $\pi$-acceptor ligands available today. Our calculations also show that embedding within a pincer framework enhances their $\pi$ acidity even further. Therefore, in addition to the stability and modularity that these frameworks offer, our pincer complexes might open the way for sulfonium cations to become powerful tools in $\pi$-acid catalysis.
\end{abstract}

Rethinking the coordination chemistry of main group elements has often led to breakthroughs in metal-based homogeneous catalysis. For instance, extending the chemistry of $\mathrm{B}, \mathrm{Al}$, $\mathrm{Ga}, \mathrm{Sn}$, and Bi gave birth to the concept of $\sigma$-acceptor (aka Ztype) ligands, ${ }^{1}$ which have been successfully applied for such fundamentally important processes as $\mathrm{N}_{2}$ fixation, ${ }^{2}$ $\mathrm{CO}_{2}$ reduction, ${ }^{3}$ and $\mathrm{H}_{2}$ activation. ${ }^{4}$

The electron-withdrawing nature of Z-type ligands also offered new opportunities for $\pi$-acid catalysis, leading to preparation of novel $\sigma$-acceptor ligands based on boranes, ${ }^{5}$ antimony, ${ }^{6}$ and carbenium ${ }^{7}$ cation. $\Pi$-acid catalysis was also significantly advanced by stretching to an extreme the $\pi$-acceptor property of phosphines ${ }^{8}$ and arsines ${ }^{9}$ through the introduction of positively charged substituents.

While seeking to unravel new facets of main group chemistry, the coordination properties of another main-group species, sulfonium cations, have been greatly overlooked. Yet, sulfonium salts are at the forefront of fundamental and applied research ${ }^{10}$ due to their countless applications as precursors for sulfur ylides, ${ }^{11}$ alkyl and aryl group sources in cross-coupling reactions, ${ }^{12}$ photoacids, ${ }^{13}$ and many others. ${ }^{14}$

Compared to the isoelectronic and isostructural tertiary phosphines, sulfonium ions have their lone pair stabilized by their positive charge, while their low-lying S-C $\sigma^{*}$-orbitals can accept electron density. Therefore, together with sulfoxonium, they have attracted the attention as non-metal Lewis acids ${ }^{15}$ and have been utilized as such for catalysis and anion sensing. ${ }^{16}$ However, while tertiary phosphines are perhaps the most iconic family of ligands, only a handful of crystallographically characterized sulfonium complexes of $\mathrm{Mo}(0), \mathrm{W}(0)$, and $\mathrm{Mn}(\mathrm{I})$ were reported decades ago, ${ }^{17}$ where these ligands exhibited strongly $\pi$-acidic character. Yet, no sulfonium complexes relevant to catalysis, have ever been reported, even though formation of transient metal-coordinated sulfonium intermediates during Pd catalyzed cross-coupling reactions of sulfonium salts has been suggested.12a
Here we report the first synthesis and characterization of a series of complexes of both aliphatic and aromatic sulfonium cations with Rh(I) and Pt(II), two metals of the Pt-group, which lies at the core of today's homogenous catalysis. Our in-depth theoretical analysis of sulfonium-metal interaction demonstrated it to be dominated by $\pi$-back bonding. This strongly $\pi$ acidic character is further enhanced by the pincer frameworks, which also provide our complexes with structural robustness and modularity, both properties of pivotal importance in catalysis. ${ }^{18}$

Obviously, coordination of sulfonium cation is hindered by an electrostatic repulsion between its positive charge and that of a metal center (even if partial). So far, the preparation of sulfonium complexes was achieved by alkylation of corresponding sulfide complexes. We adopted here a more systematic approach, where the aliphatic or aromatic sulfonium moieties were incorporated within pincer frameworks (I and II, respectively), bearing chelating phosphine arms. A similar strategy was used earlier to achieve coordination of the nitrenium cation. ${ }^{19}$

\section{Chart 1: Design of sulfonium-based pincer ligands.}

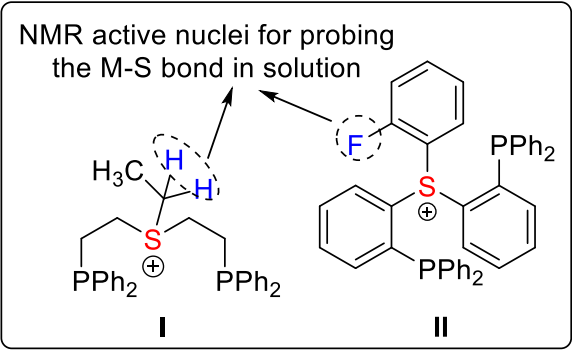

We designed aliphatic and aromatic sulfonium ligands with NMR active nuclei in the vicinity of the sulfur, namely methylene protons in I and a fluorine atom in II, that would allow detecting the formation an S-M bond in solution, by tracing 
their chemical shifts and magnetic coupling to NMR-active metal centers, ${ }^{103} \mathrm{Rh}$ and ${ }^{195} \mathrm{Pt}$.

\section{Scheme 1: Synthesis and XRD structures of sulfonium pincer ligands}

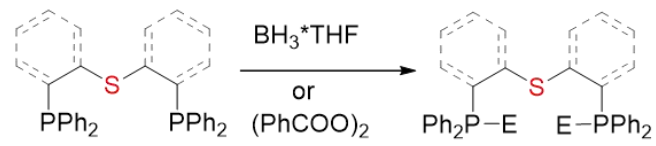

$1 a, b$

2a,b

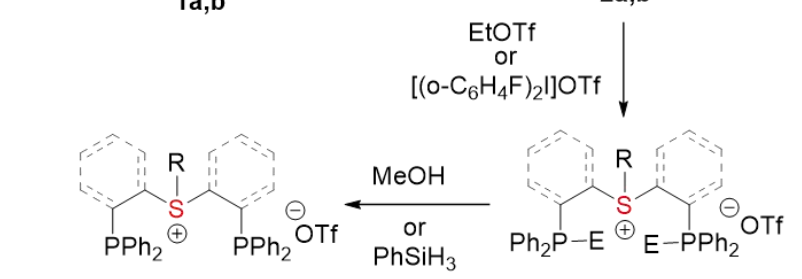

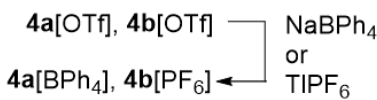

$\mathrm{E}=\mathrm{BH}_{3}(\mathbf{2 a}$ and $3 \mathbf{a}) ; \mathrm{O}(\mathbf{2 b}$ and $3 \mathbf{b})$

$\mathrm{R}=\mathrm{Et}(3 \mathrm{a}$ and $4 \mathrm{a}) ; \mathrm{o}-\mathrm{F}-\mathrm{C}_{6} \mathrm{H}_{4}(3 \mathrm{~b}$ and $4 \mathrm{~b})$

( $\mathbf{a}=$ aliphatic backbone; $\mathbf{b}=$ aromatic backbone)

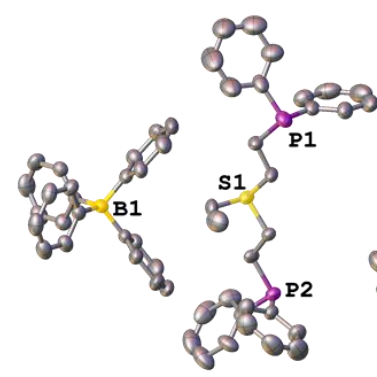

$4 \mathrm{a}\left[\mathrm{BPh}_{4}\right]$

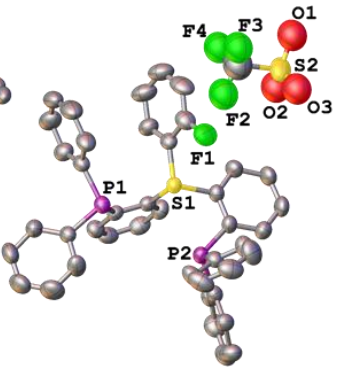

4b[OTf]
$\mathrm{H}$ atoms are omitted for clarity

Both sulfonium pincer ligands were prepared by alkylation or arylation of the corresponding bis-phosphine sulfide ligands, ${ }^{20}$ protected as borane adducts or as phosphine oxides (Scheme 1). Their deprotection resulted in ligands 4a[OTf] and $4 \mathbf{b}[0 \mathrm{Tf}]$. To obtain single crystals of the ligands and their complexes suitable for XRD analysis, the triflate counterions were in some cases exchanged to tetraphenylborate or hexafluorophosphate.

\section{Scheme 2: Synthesis of Rh(I) and Pt(II) complexes}
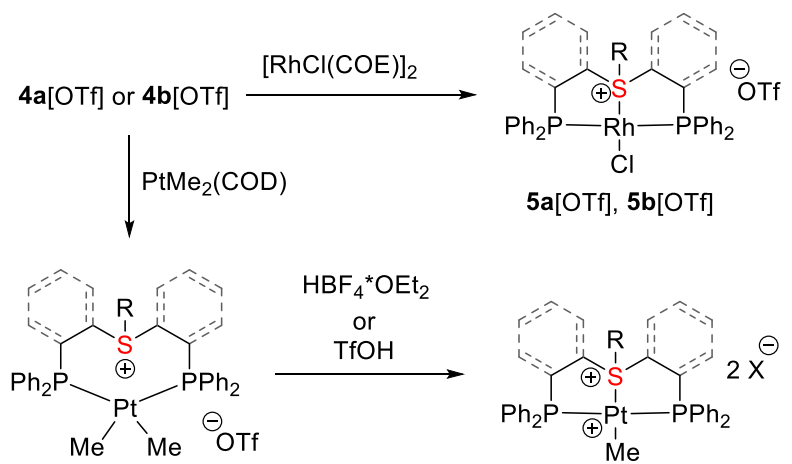

$6 \mathrm{a}[\mathrm{OTf}]$ and $\mathbf{6 b}[\mathrm{OTf}]$

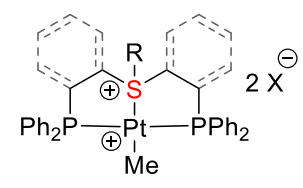

$7 \mathrm{a}\left[\mathrm{BF}_{4}\right]: \mathrm{X}=\mathrm{BF}_{4}$ $7 \mathrm{~b}[\mathrm{OTf}]: \mathrm{X}=\mathrm{OTf}$

( $\mathbf{a}=$ aliphatic backbone; $\mathbf{b}=$ aromatic backbone $)$

The coordinative behavior of the aliphatic sulfonium ligand 4a[OTf] towards $\mathrm{Rh}(\mathrm{I})$ was tested by reacting it with [RhCl(COE) $\left.]_{2}\right]_{2}$ (Scheme 2). A full conversion to a symmetric $\mathrm{Rh}(\mathrm{I})$ complex was evident by ${ }^{31} \mathrm{P} \mathrm{NMR}$, as the chemical shift moved from a singlet at $-18.2 \mathrm{ppm}$ to a doublet at $+46.4 \mathrm{ppm}$ $\left({ }^{1} J_{\mathrm{Rh}-\mathrm{P}}=127.8 \mathrm{~Hz}\right)$. In the ${ }^{1} \mathrm{H}$ NMR spectrum, significant downfield shifts of all aliphatic signals is observed. Each of the methylene protons signals $\mathbf{a}$ and $\mathbf{b}$ (Figure 1), divides upon coordination into two (a* and $\mathbf{b}^{*}$ pairs, respectively), indicating formation of a rigid structure with no rotation around $\mathrm{C}-\mathrm{C}$ bonds. Furthermore, an additional splitting of $1.3 \mathrm{~Hz}$ appears in the quartet assigned to the ethyl tail methylene protons ( $\left.\mathbf{c}^{*}\right)$. By means of ${ }^{1} \mathrm{H}-{ }^{103} \mathrm{Rh}$ HMBC (Figure S3), this splitting was attributed to a through-bonds ${ }^{3} J_{\mathrm{Rh}-\mathrm{H}}$ interaction. The latter is only possible if sulfonium is coordinated to the Rh center.

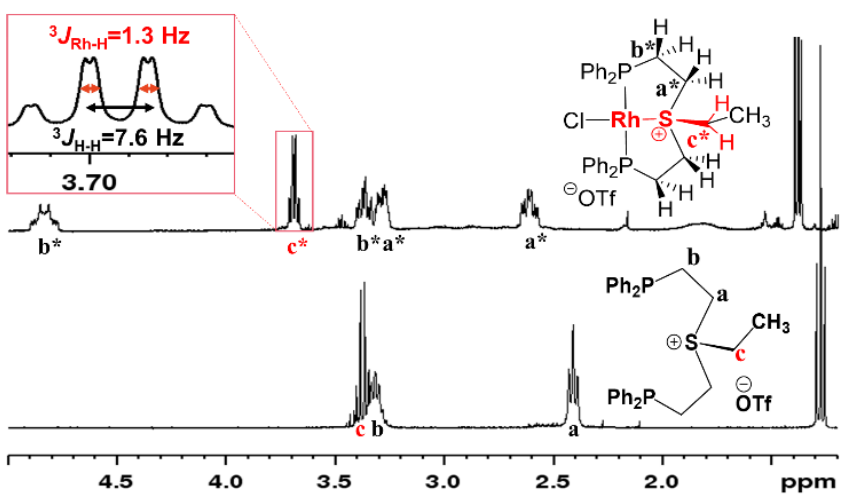

Figure 1: Aliphatic region of ${ }^{1} \mathrm{H}$ NMR spectra of $4 \mathrm{a}[\mathrm{OTf}]$ and $5 a[0 T f]$.

Encouraged by these results, we then turned to the aromatic ligand $\mathbf{4 b}$ [OTf] (Scheme 2). Here also, a full conversion of the ligand to a symmetric Rh(I) complex 5b[OTf] was evident from the ${ }^{31} \mathrm{P}$ NMR spectrum, where the chemical shift changed from a singlet at $-12.9 \mathrm{ppm}$ to a doublet of doublets at $+48.6 \mathrm{ppm}\left({ }^{1} J_{\mathrm{Rh}}\right.$

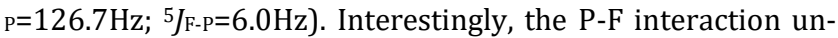
observable in the spectrum of the free ligand, became noticeable after coordination, perhaps due to the additional rigidity of the formed complex.

The ${ }^{19} \mathrm{~F}$ NMR spectrum of $\mathbf{5 b}[\mathrm{OTf}]$ showed only a small downfield shift compared to the free ligand (-104.1 vs $105.3 \mathrm{ppm}$, respectively) and no additional splitting by ${ }^{103} \mathrm{Rh}$ could be identified. Likewise, no ${ }^{19} \mathrm{~F}-103 \mathrm{Rh}$ interactions could be detected by HMBC, hence in this case, metal coordination to aromatic sulfonium moiety could not be validated by NMR alone.

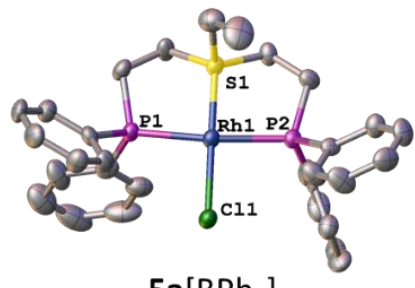

$5 \mathrm{a}\left[\mathrm{BPh}_{4}\right]$

S1-Rh1 = 2.126(3) Å

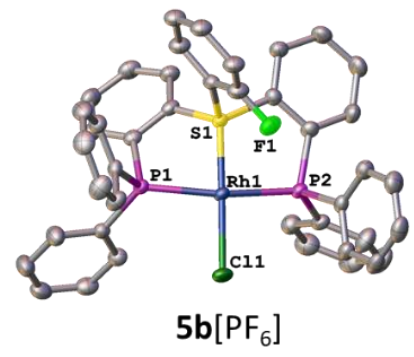

S1-Rh1 = 2.1117(6) $\AA$
Counteranions and $\mathrm{H}$ atoms are omitted for clarity

Figure 2: XRD structures of $\mathrm{Rh}(\mathrm{I})$-sulfonium complexes, $\mathbf{5 a}\left[\mathrm{BPh}_{4}\right]$ and $\mathbf{5 b}\left[\mathrm{PF}_{6}\right]$.

Nevertheless, the irrefutable evidence of sulfonium-Rh bonding in both systems was provided by XRD. Both complexes 
$\mathbf{5 a}\left[\mathrm{BPh}_{4}\right]$ and $\mathbf{5 b}\left[\mathrm{PF}_{6}\right]$ exhibited a slightly distorted square-planar geometry around the metal, typical of $\mathrm{d}^{8}$ complexes (Figure 2). The sulfonium-Rh(I) bond lengths of 2.126(3) and $2.1117(6) \AA ̊$ in $\mathbf{5} \mathbf{a}\left[\mathrm{BPh}_{4}\right]$ and $\mathbf{5 b}\left[\mathrm{PF}_{6}\right]$, respectively, are among the shortest reported $\mathrm{S}-\mathrm{Rh}$ bonds. These are significantly shorter than in $\mathrm{Rh}(\mathrm{I})$ complexes with sulfides $(>2.24 \AA)$ and

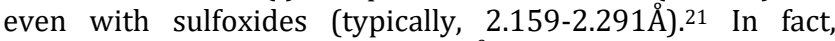
shorter Rh(I)-S bonds (2.069-2.100A) were only observed with the strongest $\pi$-acceptor ligands: $\mathrm{SO}_{2}{ }^{22}$ and the related N-sulfinylaniline. ${ }^{23}$ These exceptionally short bonds in $\mathbf{5 a}\left[\mathrm{BPh}_{4}\right]$ and $\mathbf{5 b}\left[\mathrm{PF}_{6}\right]$ cannot be explained solely by the grip of the pincer framework. Indeed, in both the analogous aliphatic sulfoxide pincer complex 8 that we prepared (see SI) and the reported aromatic ones, ${ }^{24}$ the $\mathrm{Rh}-\mathrm{S}$ bonds are still longer than in their sulfonium counterparts (2.135 and $2.134 \AA$, respectively).

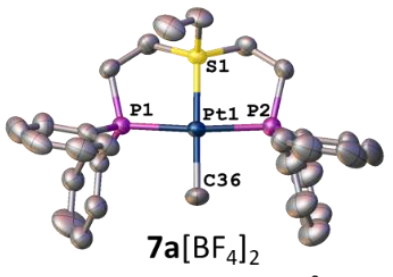

S1-Pt1 = 2.258(1) ^

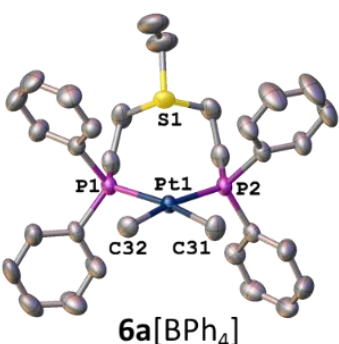

$\mathrm{S} 1 \bullet \bullet \cdot \mathrm{Pt}=3.7756(8) \AA$

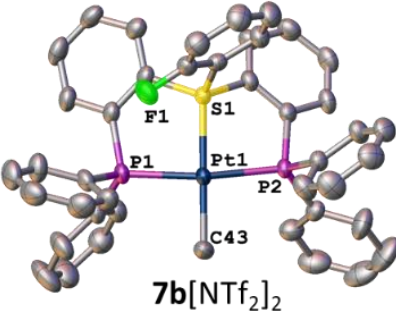

S1-Pt1 $=2.260(1) \AA$

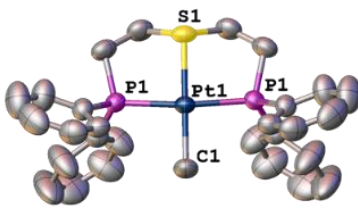

$9\left[\mathrm{BF}_{4}\right]$

$\mathrm{S} 1-\mathrm{Pt} 1=2.336(2) \AA$
Counteranions and $\mathrm{H}$ atoms are omitted for clarity

Figure 3: XRD structures of $\mathrm{Pt}(\mathrm{II})$ complexes, $\mathbf{6 a}\left[\mathrm{BPh}_{4}\right]$, $\mathbf{7 a}\left[\mathrm{BF}_{4}\right]_{2}, \mathbf{7} \mathbf{b}\left[\mathrm{NTf}_{2}\right]_{2}$, and $\mathbf{9}\left[\mathrm{BF}_{4}\right]$.

Having achieved sulfonium coordination to the neutral $\mathrm{RhCl}$ unit, we wondered whether, similarly to cationic nitrenium ${ }^{19 b}$ and arenium $^{25}$ pincers, our frameworks could also induce bonding between a sulfonium cation, and a positively charged metal fragment.

Therefore, we first treated ligands 4a[OTf] and $\mathbf{4 b}$ [0Tf] with $\mathrm{Pt}(\mathrm{COD}) \mathrm{Me}_{2}$ which resulted in new compounds (Scheme 2), as evident from ${ }^{31} \mathrm{P}$ NMR spectrum that exhibited downfield shifted peaks at 11.3 or $16.6 \mathrm{ppm}$ with the characteristic ${ }^{195 \mathrm{Pt}}$ satellites $\left({ }^{1} J_{\mathrm{Pt}-\mathrm{P}}=1813 \mathrm{~Hz}\right.$ and $1781 \mathrm{~Hz}$, respectively). In the ${ }^{1} \mathrm{H}$ NMR signals at 0.42 and $0.65 \mathrm{ppm}$, were assigned to the methyl protons, confirming the formation of $\mathrm{PtMe}_{2}$ complexes 6a[OTf] and $\mathbf{6 b}[\mathrm{OTf}]$, respectively. Moreover, these signals appeared as doublets of doublets due to splitting by two magnetically inequivalent $\mathrm{P}$ atoms, a configuration only possible when methyl groups are oriented cis to each other (Figures S1, S2).

The neutral $\mathrm{PtMe}_{2}$ fragment in $\mathbf{6 a}[\mathrm{OTf}]$ and $\mathbf{6 b}[\mathrm{OTf}]$ was then transformed into a cation by protonolysis (by $\mathrm{HBF}_{4}{ }^{*} \mathrm{OEt}_{2}$ or HOTf) which resulted in the clean formation of complexes $\mathbf{7 a}\left[\mathrm{BF}_{4}\right]_{2}$ and $\mathbf{7 b}$ [OTf $]_{2}$ (Scheme 2), as attested by new peaks at $42.4\left(1 J_{\mathrm{Pt}-\mathrm{P}}=2736 \mathrm{~Hz}\right)$ and $44.3\left({ }^{1} \mathrm{Jt}_{\mathrm{Pt}-\mathrm{P}}=2768 \mathrm{~Hz}\right) \mathrm{ppm}$, respectively, in ${ }^{31} \mathrm{P}$ NMR. In the aromatic complex $\mathbf{7 b}[\mathrm{OTf}] 2$ the ${ }^{31} \mathrm{P}$ NMR signals were much sharper than in $\mathbf{6 b}[0 \mathrm{Tf}]$, and similarly to the $\mathrm{Rh}(\mathrm{I})$ complex $\mathbf{5 b}[\mathrm{OTf}]$, splitting due to the P-F coupling $\left(5 J_{\mathrm{P}-\mathrm{F}}=4 \mathrm{~Hz}\right)$ became observable.

Unlike complexes $\mathbf{6 a}[\mathrm{OTf}]$ and $\mathbf{6 b}[\mathrm{OTf}]$, in both $\mathbf{7 a}\left[\mathrm{BF}_{4}\right]_{2}$ and $\mathbf{7 b}[\mathrm{OTf}]_{2}$, the ${ }^{1} \mathrm{H}$ NMR signals at 1.21 and $1.56 \mathrm{ppm}$, corresponding to single methyls, appeared as triplets indicating magnetic equivalence of the two phosphines, only possible in a mutual trans-orientation (Figures S1, S2). Moreover, the signals of the aliphatic protons in $\mathbf{7 a}\left[\mathrm{BF}_{4}\right]_{2}$ followed a pattern similar to that of 5a[0Tf] (Figure 1), suggesting an analogous structure (Figure S1). To further study sulfonium-Pt interaction in solution we applied ${ }^{1} \mathrm{H}-{ }^{195} \mathrm{Pt} \mathrm{HMBC}$, once again focusing on magnetic interaction between $\mathrm{Pt}$ and the methylene protons of the ethyl tail (Figure S4). While in 6a[OTf] this coupling constant is negligible $\left(0.2 \mathrm{~Hz}\right.$, presumably due to $\left.{ }^{6} \mathrm{Jt}_{\mathrm{Pt}-\mathrm{H}}\right)$, in $\mathbf{7 a} \mathbf{a}\left[\mathrm{BF}_{4}\right]_{2}$ it reaches 7.7 Hz (most likely, due to ${ }^{3} \mathrm{Pt}_{\mathrm{Pt}}$ ), suggesting the presence of SPt bond in $\mathbf{7 a}\left[\mathrm{BF}_{4}\right]_{2}$, but not in $\mathbf{6 a}$ [OTf]. Similar conclusion about S-Pt bonding in $\mathbf{6 b}[\mathrm{OTf}]$ and $\mathbf{7 b}[\mathrm{OTf}]_{2}$ could be drawn by comparing their ${ }^{19} \mathrm{~F}-195 \mathrm{Pt} \mathrm{HMBC}$ spectra (Figure S5), even though both complexes exhibited nearly identical chemical shifts in ${ }^{19} \mathrm{~F}$ NMR (-102.28 and $-102.45 \mathrm{ppm}$, respectively). The former showed no ${ }^{19} \mathrm{~F}-195 \mathrm{Pt}$ correlation, while the latter revealed a prominent cross-peak with a coupling constant of $3.3 \mathrm{~Hz}$, supporting the presence of sulfonium-Pt bond. a

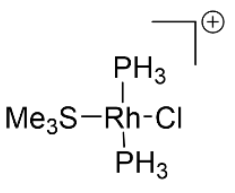

$10 \mathrm{a}$

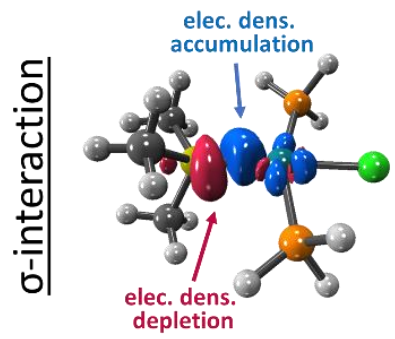

$\Delta \rho_{2}: \Delta E_{\text {orb2 }}=-32.12$

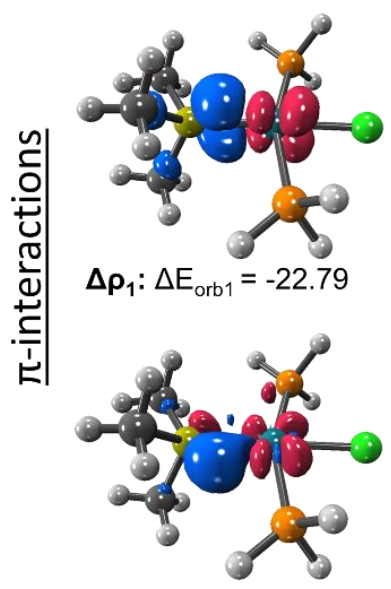

$\Delta \rho_{3}: \Delta E_{\text {orb3 }}=-20.95$ b<smiles>CC(C)C</smiles>

$17 a$

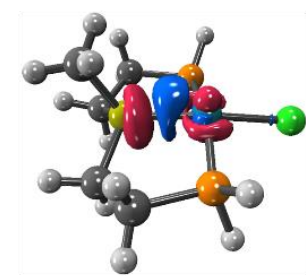

$\Delta \rho_{5}: \Delta E_{\text {orb5 }}=-19.83$

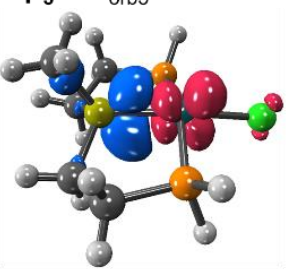

$\Delta \rho_{2}: \Delta \mathrm{E}_{\text {orb2 }}=-33.24$

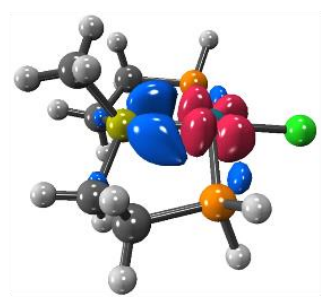

$\Delta \rho_{3}: \Delta E_{\text {orb3 }}=-29.87$
All energies are given in $\mathrm{kcal} / \mathrm{mol}$

Figure 4: Selected deformation density plots of model complexes 10a and 17a.

Ultimately, the solid-state structures of $\mathbf{6} \mathbf{a}\left[\mathrm{BPh}_{4}\right], \mathbf{7} \mathbf{a}\left[\mathrm{BF}_{4}\right]_{2}$, and $\mathbf{7} \mathbf{b}\left[\mathrm{NTf}_{2}\right]_{2}$ were established by single crystal XRD (Figure 
3). In $\mathbf{6 a}\left[\mathrm{BPh}_{4}\right]$, as expected from the NMR analysis, no Pt-S bond was observed, and the methyl groups indeed exhibited a cis configuration. However, in $\mathbf{7 a}\left[\mathrm{BF}_{4}\right]_{2}$ and $\mathbf{7 b}\left[\mathrm{NTf}_{2}\right]_{2}, \mathrm{Pt}-\mathrm{S}$ bonds of $2.258(1)$ and $2.261(1) \AA$, respectively, were found. Surprisingly, despite electrostatic repulsion between the cationic sulfonium and the PtMe fragment, this bond in $\mathbf{7 a}\left[\mathrm{BF}_{4}\right]_{2}$ is shorter than that in its neutral sulfide analog $9\left[\mathrm{BF}_{4}\right], 2.336(2) \AA$, prepared for comparison (Figure 3).

The exceptionally short metal-sulfonium bonds mostly observed in our Rh complexes prompted us to undertake a computational investigation by DFT, applying the Energy Decomposition Analysis ${ }^{26}$ combined with the Natural Orbital for Chemical Valence theory (EDA-NOCV). ${ }^{27,28}$ This method provides a series of density deformation maps $\left(\Delta \rho_{n}\right)$ describing the interactions between isolated system components. The energy of the orbital interactions $\left(\Delta \mathrm{E}_{\mathrm{orb}}\right)$ is then extracted from the overall interactions $\left(\Delta \mathrm{E}_{\mathrm{int}}\right)$ and decomposed into constituents according to their symmetry.

First, we considered the Rh-S bonding interactions in the model monodentate aliphatic and aromatic sulfonium complexes 10a and 10b and compared them with analogous complexes of neutral phosphines, sulfides and sulfoxides, as well as with a few representative cationic ligands. By inspecting the deformation density maps of the most significant orbital interactions $\left(\Delta \mathrm{E}_{\mathrm{orb}}\right)$, we could identify a single $\sigma$-symmetric interaction, which contrary to the reported $\mathrm{M} \rightarrow \mathrm{L}$ interaction in the isoelectronic telluronium complex, ${ }^{29}$ has a clear $\mathrm{L} \rightarrow \mathrm{M}$ donation character, and two $\pi$-symmetric ones (perpendicular and parallel to the coordination plane) corresponding to the $\mathrm{M} \rightarrow \mathrm{L}$ back-donation (see representative deformation density maps of 10a in Figure 4a, for other maps see SI).

Table 1 shows that in terms of their BDEs and $\sigma$-donation, sulfonium cations are nearly similar to sulfides and sulfoxides. However, sulfonium cations are significantly stronger $\pi$-acceptors, with $\pi$-back-bonding interaction being predominant. This is quite unusual, and not the case even for the strongly $\pi$-acidic perfluorinated phosphines (in complexes 14a-c), where similarly to common phosphines (in 13a,b), $\sigma$-donation still prevails. This predominance of $\pi$-back-donation over $\sigma$-donation appears specific only to cationic ligands considered here. Compared to the latter, the $\pi$-acidity of sulfonium stands between that of $\mathrm{N}$-heterocyclic nitrenium $\left([\mathrm{NHN}]^{+}\right.$, in 15a) and N-heterocyclic phosphenium ([NHP]+, in 15b), and is comparable to Alcarazo's tris-cationic phosphine $\mathrm{PR}^{3+}$ (in 15c). Calculations performed on model Rh complexes 17a,b (Table 2) showed that geometry deformations imposed by the pincer frameworks (Figures S17, S18 and the explanation therein) further weakens $\sigma$-donation, but strengthens $\pi$-back donation within the complexes.

With the cationic PtMe fragment in sulfonium complexes 16a,b (Table 1) that are kinetically stable despite their positive BDEs, $\pi$-back-bonding is still non-negligible, albeit much weaker than in 10a,b. Nevertheless, in the corresponding pincer complexes 18a,b (Table 2), it drastically increases, becoming comparable to the $\sigma$-donation.

Table 1: EDA-NOCV data for the monodentate $\left[\mathrm{L}\left(\mathrm{PH}_{3}\right)_{2} \mathrm{MX}\right]^{\mathrm{n}+}$ complexes.

\begin{tabular}{|c|c|c|c|c|c|c|c|c|}
\hline \multirow{3}{*}{$\begin{array}{c}\text { MX } \\
\text { Ligand Types } \\
\text { Model } \\
\text { Complexes }\end{array}$} & \multicolumn{8}{|c|}{$\mathrm{RhCl}$} \\
\hline & \multicolumn{2}{|c|}{ Sulfonium cations } & \multicolumn{2}{|c|}{ Sulfides } & \multicolumn{2}{|c|}{ Sulfoxides } & \multicolumn{2}{|c|}{ Phosphines } \\
\hline & $10 a$ & $10 \mathrm{~b}$ & 11a & 11b & 12a & $12 b$ & 13a & 13b \\
\hline $\mathrm{L}$ & $\mathrm{SMe}_{3}+$ & $\mathrm{SPh}_{3}{ }^{+}$ & $\mathrm{SMe}_{2}$ & $\mathrm{SPh}_{2}$ & DMSO & $\mathrm{Ph}_{2} \mathrm{SO}$ & $\mathrm{PMe}_{3}$ & $\mathrm{PPh}_{3}$ \\
\hline BDE* & -38.57 & -36.96 & -36.21 & -38.19 & -39.82 & -44.55 & -70.06 & -57.77 \\
\hline $\begin{array}{c}\sigma \text {-bonding* } \\
\text { ( } \% \text { of } \sigma / \Delta \mathrm{E}_{\text {orb }} \text { ) }\end{array}$ & $\begin{array}{c}-32.12 \\
(37.3 \%)\end{array}$ & $\begin{array}{c}-31.00 \\
(31.0 \%)\end{array}$ & $\begin{array}{c}-34.89 \\
(63.5 \%)\end{array}$ & $\begin{array}{c}-34.25 \\
(61.0 \%)\end{array}$ & $\begin{array}{c}-39.65 \\
(57.1 \%)\end{array}$ & $\begin{array}{c}-40.57 \\
(53.5 \%)\end{array}$ & $\begin{array}{c}-56.46 \\
(67.3 \%)\end{array}$ & $\begin{array}{c}-53.10 \\
(63.3 \%)\end{array}$ \\
\hline $\begin{array}{c}\pi \text {-backbonding*t } \\
\text { ( } \% \text { of } \pi / \Delta \mathrm{E}_{\text {orb }} \text { ) }\end{array}$ & $\begin{array}{c}-43.74 \\
(50.8 \%)\end{array}$ & $\begin{array}{c}-39.24 \\
(39.2 \%)\end{array}$ & $\begin{array}{c}-14.83 \\
(27.0 \%)\end{array}$ & $\begin{array}{c}-16.04 \\
(28.6 \%)\end{array}$ & $\begin{array}{c}-24.31 \\
(35.0 \%)\end{array}$ & $\begin{array}{c}-28.80 \\
(38.0 \%)\end{array}$ & $\begin{array}{c}-21.98 \\
(26.2 \%)\end{array}$ & $\begin{array}{c}-24.08 \\
(28.7 \%)\end{array}$ \\
\hline
\end{tabular}

\begin{tabular}{|c|c|c|c|c|c|c|c|c|}
\hline MX & \multicolumn{6}{|c|}{$\mathrm{RhCl}$} & \multirow{2}{*}{\multicolumn{2}{|c|}{$\begin{array}{c}\mathrm{PtMe}^{+} \\
\text {Sulfonium cations }\end{array}$}} \\
\hline Ligand Type & \multicolumn{3}{|c|}{ Perfluorinated phosphines } & \multicolumn{3}{|c|}{ Cationic Ligands } & & \\
\hline $\begin{array}{c}\text { Model } \\
\text { Complex }\end{array}$ & 14a & 14b & 14c & 15a & $15 b$ & $15 \mathrm{c}$ & 16a & 16b \\
\hline $\mathrm{L}$ & $\mathrm{PF}_{3}$ & $\mathrm{P}\left(\mathrm{CF}_{3}\right)_{3}$ & $\mathrm{P}\left(\mathrm{C}_{6} \mathrm{~F}_{5}\right)_{3}$ & ${ }_{[\mathrm{NHN}]^{+}}^{\mathrm{N}}$ & ${ }_{[\mathrm{NHP}]^{+}}$ & {$\left[\mathrm{PR}_{3}\right]^{3+}$} & $\mathrm{SMe}_{3}{ }^{+}$ & $\mathrm{SPh}_{3}{ }^{+}$ \\
\hline BDE* & -56.76 & -53.16 & -51.35 & -30.55 & -57.57 & -53.16 & +48.60 & +30.66 \\
\hline $\begin{array}{c}\sigma \text {-bonding* } \\
\text { ( } \% \text { of } \sigma / \Delta \mathrm{E}_{\text {orb }} \text { ) }\end{array}$ & $\begin{array}{c}-51.61 \\
(51.4 \%)\end{array}$ & $\begin{array}{c}-46.69 \\
(49.7 \%)\end{array}$ & $\begin{array}{c}-47.59 \\
(55.1 \%)\end{array}$ & $\begin{array}{c}-25.20 \\
(40.3 \%)\end{array}$ & $\begin{array}{c}-42.75 \\
(44.3 \%)\end{array}$ & $\begin{array}{l}-44.25 \\
(42.6 \%)\end{array}$ & $\begin{array}{l}-33.60 \\
(57.3)\end{array}$ & $\begin{array}{l}-32.71 \\
(56.9)\end{array}$ \\
\hline $\begin{array}{c}\pi \text {-backbonding*十 } \\
\text { ( } \% \text { of } \pi / \Delta \mathrm{E}_{\text {orb }} \text { ) }\end{array}$ & $\begin{array}{c}-43.42 \\
(43.3 \%)\end{array}$ & $\begin{array}{c}-40.58 \\
(43.2 \%)\end{array}$ & $\begin{array}{c}-32.08 \\
(37.1 \%)\end{array}$ & $\begin{array}{c}-29.07 \\
(46.4 \%)\end{array}$ & $\begin{array}{c}-62.16 \\
(52.3 \%)\end{array}$ & $\begin{array}{c}-45.99 \\
(44.2 \%)\end{array}$ & $\begin{array}{c}-17.12 \\
(29.2 \%)\end{array}$ & $\begin{array}{l}-13.48 \\
(23.5)\end{array}$ \\
\hline
\end{tabular}

${ }^{*}$ Energies are given in $\mathrm{kcal} / \mathrm{mol}$, † Sum of the $\perp$ and $\| \pi$-interactions 
Table 2: EDA-NOCV data for the [LMX $]^{\text {n+ }}$ sulfonium pincer complexes.

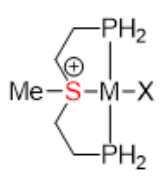

$17 a, 18 a$

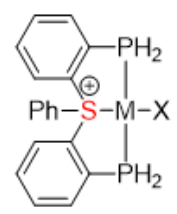

$17 b, 18 b$

\begin{tabular}{|c|c|c|c|c|}
\hline MX & \multicolumn{2}{|c|}{$\mathrm{RhCl}$} & \multicolumn{2}{|c|}{$\mathrm{PtMe}^{+}$} \\
\hline Model Complex & $17 \mathbf{a}$ & $17 \mathrm{~b}$ & 18a & 18b \\
\hline$\sigma$-bonding* & -19.83 & -18.10 & -46.97 & -44.84 \\
\hline 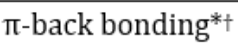 & -62.11 & -58.86 & -39.88 & -41.4 \\
\hline
\end{tabular}

* Energies are given in $\mathrm{kcal} / \mathrm{mol}$, † Sum of the $\perp$ and $\|$-interactions

To summarize, in this paper we have consolidated the status of sulfonium ions among the family of rare cationic ligands demonstrating for the first time that their coordination chemistry can be extended to the Pt group metals. We also prepared the very first examples of a metal-coordinated aromatic sulfonium cations. These unusual compounds might represent stable analogs of possible transient intermediates forming during Pd-catalyzed cross-coupling of sulfonium salts.

Our calculations suggested that sulfonium cations are among the best $\pi$-acceptors available. Moreover, the pincer frameworks which offers an additional robustness also intensify this propensity. These scaffolds might therefore be the key to transform sulfonium complexes from a chemical curiosity into potential $\pi$-acid catalysts, the applications of which is currently studied in our lab.

\section{Acknowledgments}

We would like to thank Prof. Chris H. Hendon and Mr. MinChieh Yang from the University of Oregon, USA, for valuable advice in our computational studies. R.L. expresses her gratitude for the CSC-HUJI fellowship. We thank Dr. Roy Hoffman for his assistance in performing 2D ${ }^{103} \mathrm{Rh}$ and ${ }^{195} \mathrm{Pt}$ NMR measurements. Our deep gratitude is also given to our colleagues from the Hebrew University, Prof. Dmitri Gelman, Prof. Avi Bino and Prof. Silvio Biali, for their kind help and support throughout our research.
1 a) You, D.; Gabbaï, F. P. Trends Chem. 2019, 1, 485- 496; b) Amgoune, A.; Bourissou, D. Chem. Commun. 2011, 47, 859- 871.

2 a) Cammarota, R. C.; Clouston, L. J.; Lu, C. C. Coord. Chem. Rev. 2017, 334, 100-111; b) Anderson, J. S.; Rittle, J.; Peters, J. C. Nature 2013, 501, 84- 87; c) Del Castillo, T. J.; Thompson, N. B.; Peters, J. C. J. Am. Chem. Soc. 2016, 138, 5341- 5350; d) Fajardo, J., Jr.; Peters, J. C. Inorg. Chem. 2021, 60, 1220- 1227; e) Suess, D. L.; Peters, J. C. J. Am. Chem. Soc. 2013, 135, 4938- 4941; g) Siedschlag, R. B.; Bernales, V.; Vogiatzis, K. D.; Planas, N.; Clouston, L. J.; Bill, E.; Gagliardi, L.; Lu, C. C. J. Am. Chem. Soc. 2015, 137, 4638-4641.

3 a) Takaya, J.; Iwasawa, N. Synthesis, J. Am. Chem. Soc. 2017, 139, 6074- 6077; b) Devillard, M.; Declercq, R.; Nicolas, E.; Ehlers, A. W.; Backs, J.; Saffon-Merceron, N.; Bouhadir, G.; Slootweg, J. C.; Uhl, W.; Bourissou, $\quad$ D. J. Am. Chem. Soc. 2016, 138, 4917-4926; c) Ye, J.; Cammarota, R. C.; Xie, J.; Vollmer, M. V.; Truhlar, D. G.; Cramer, C. J.; Lu, C. C.; Gagliardi, L. ACS Catal. 2018, 8, 4955- 4968; d) Vollmer, M. V.; Ye, J.; Linehan, J. C.; Graziano, B. J.; Preston, A.; Wiedner, E. S.; Lu, C. C. ACS Catal. 2020, 10, 2459- 2470.

${ }^{4}$ a) Barnett, B. R.; Moore, C. E.; Rheingold, A. L.; Figueroa, J. S. J. Am. Chem. Soc. 2014, 136, 10262-10265; b) Ramirez, B. L.; Lu, C. C. J. Am. Chem. Soc. 2020, 142, 5396- 5407; c) Moore, J. T.; Lu, C. C. J. Am. Chem. Soc. 2020, 142, 11641- 11646; d) Cammarota, R. C.; Xie, J.; Burgess, S. A.; Vollmer, M. V.; Vogiatzis, K. D.; Ye, J.; Linehan, J. C.; Appel, A. M.; Hoffmann, C.; Wang, X.; Young, V. G.; Lu, C. C. Chem. Sci. 2019, 10, 7029- 7042; e) Cammarota, R. C.; Vollmer, M. V.; Xie, J.; Ye, J.; Linehan, J. C.; Burgess, S. A.; Appel, A. M.; Gagliardi, L.; Lu, C. C. J. Am. Chem. Soc. 2017, 139, 14244-14250; f) Graziano, B. J.; Vollmer, M. V.; Lu, C. C. Angew. Chem., Int. Ed. 2021, 60, 1508715094.

5 a) Inagaki, F.; Matsumoto, C.; Okada, Y.; Maruyama, N.; Mukai, C. Angew. Chem., Int. Ed. 2015, 54, 818- 822; b) Inagaki, F.; Nakazawa, K.; Maeda, K.; Koseki, T.; Mukai, C. Organometallics 2017, 36 , 3005-3008; c) Murakami, R.; Tanishima, H.; Naito, D.; Kawamitsu, H.; Kamo, R.; Uchida, A.; Kawasaki, K.; Kiyohara, C.; Matsuo, M.; Maeda, K.; Inagaki, F. Tetrahedron Letters 2021, 78, 153267; d) Murakami, R.; Inagaki, F. Tetrahedron Lett. 2019, 60, 151231; e) Ueno, A.; Watanabe, K.; Daniliuc, C. G.; Kehr, G.; Erker, G. Chem. Commun.
2019, 55, 4367- 4370, f) Inagaki, F.; Maeda, K.; Nakazawa, K. Mukai, C. Eur. J. Org. Chem. 2018, 2972- 2976.

${ }^{6}$ a) Yang, H.; Gabbai, F. P. J. Am. Chem. Soc. 2015, 137, 1342513432; b) Sen, S.; Ke, I.-S.; Gabbaï, F. P. Organometallics 2017, 36, 4224- 4230; c) You, D.; Yang, H.; Sen, S.; Gabbaï, F. P. J. Am. Chem. Soc. 2018, 140, 9644-9651; d) Lo, Y.-H.; Gabbaï, F. P. Angew. Chem., Int. Ed. 2019, 58, 10194- 10197; e) You, D.; Gabbaï, F. P. J. Am. Chem. Soc. 2017, 139, 6843- 6846; f) You, D.; Smith, J. E.; Sen, S.; Gabbaï, F. P. Organometallics 2020, 39, 4169-4173.

7 a) Wilkins, L. C.; Kim, Y.; Litle, E. D.; Gabbaï, F. P. Angew. Chem., Int. Ed. 2019, 58, 18266- 18270; Angew. Chem. 2019, 131, 18434 18438; b) Litle, E. D., Wilkins, L. C.; Gabbaï , F. P. Chem. Sci., 2021, 12,3929 .

8 a) Alcarazo, M. Acc. Chem. Res. 2016, 49, 1797- 1805; b) Redero, P.; Hartung, T.; Zhang, J.; Nicholls, L. D. M.; Zichen, G.; Simon, M.; Golz, C.; Alcarazo, M. Angew. Chem., Int. Ed. 2020, 59, 23527; c) Johannsen, T.; Golz, C.; Alcarazo, M. Angew. Chem., Int. Ed. 2020, 59, 22779- 22784; d) Zhang, J.; Simon, M.; Golz, C.; Alcarazo, M. Angew. Chem., Int. Ed. 2020, 59, 5647- 5650; e) Hartung, T.; Machleid, R.; Simon, M.; Golz, C.; Alcarazo, M. Angew. Chem., Int. Ed. 2020, 59, 5660- 5664; f) Gu, L.; Wolf, L. M.; Zieliński, A.; Thiel, W.; Alcarazo, M. J. Am. Chem. Soc. 2017, 139, 4948- 4953; g) GonzálezFernández, E.; Nicholls, L. D. M.; Schaaf, L. D.; Farès, C.; Lehmann, C. W.; Alcarazo, M. J. Am. Chem. Soc. 2017, 139, 1428- 1431; h) Tinnermann, H.; Wille, C.; Alcarazo, M. Angew. Chem., Int. Ed. 2014, 53, 8732- 8736; i) Carreras, J.; Gopakumar, G.; Gu, L.; Gimeno, A.; Linowski, P.; Petuškova, J.; Thiel, W.; Alcarazo, M. J. Am. Chem. Soc. 2013, 135, 18815- 18823; j) Carreras, J.; Patil, M.; Thiel, W.; Alcarazo, M. J. Am. Chem. Soc. 2012, 134, 16753- 16758.

${ }^{9}$ Dube, J. W.; Zheng, Y.; Thiel, W.; Alcarazo, M. J. Am. Chem. Soc. 2016, 138, 6869- 6877.

10 a) Kozhushkov, S. I.; Alcarazo, M. Eur. J. Inorg Chem. 2020, 2020, 2486- 2500; Kaiser, D.; Klose, I.; Oost, R.; Neuhaus, J.; Maulide, N. Chem. Rev. 2019, 119, 8701-8780; b) c) Nenaidenko, V. G.; Balenkova, E. S. Russ. J. Org. Chem. 2003, 39, 291- 330.

${ }^{11}$ For detailed reviews, see: a) Lu, L.-Q.; Li, T.-R.; Wang, Q.; Xiao, W.-J. Chem. Soc. Rev. 2017, 46, 4135- 4149; b) Aggarwal, V. K.; 
Winn, C. L. Acc. Chem. Res. 2004, 37, 611-620; c) Burtoloso, A. C. B.; Dias, R. M. P.; Leonarczyk, I. A. Eur. J. Org. Chem. 2013, 50055016. For representative examples, see: d) Corey, E. J.; Chaykovsky, M. J. Am. Chem. Soc. 1962, 84, 3782- 3783; e) Corey, E. J.; Chaykovsky, M. J. Am. Chem. Soc. 1965, 87, 1353-1364; f) Huang, X.; Patil, M.; Farès, C.; Thiel, W.; Maulide, N. J. Am. Chem. Soc. 2013, 135, 7312- 7323. g) Appel, R.; Hartmann, N.; Mayr, H. J. Am. Chem. Soc. 2010, 132, 17894- 1790.

12 a) Srogl, J.; Allred, G. D.; Liebeskind, L. S. J. Am. Chem. Soc. 1997, 119, 12376-12377; b) Berger, F., Plutschack, M.B., Riegger, J. et al. Nature, 2019, 567, 223-228; c) Engl, P. S.; Häring, A. P.; Berger, F.; Berger, G.; Pérez-Bitrián, A.; Ritter, T. J. Am. Chem. Soc. 2019, 141, 13346-13351; d) Jia, H.; Häring, A. P.; Berger, F.; Zhang, L.; Ritter, T. J. Am. Chem. Soc. 2021, 143, 7623-7628; e) Alvarez, E. M.; Karl, T.; Berger, F.; Torkowski, L.; Ritter, T. Angew. Chem. Int. Ed. 2021, 60, 13609 -13613; f) Chen, J. T.; Li, J. K.; Plutschack, M. B.; Berger, F.; Ritter, T. Angew. Chem., Int. Ed. 2020, 59, 5616- 5620; g) Xu, P.; Zhao, D.; Berger, F.; Hamad, A.; Rickmeier, J.; Petzold, R.; Kondratiuk, M.; Bohdan, K.; Ritter, T. Angew. Chem., Int. Ed. 2020, 59, 1956- 1960; h) Li, J.; Chen, J.; Sang, R.; Ham, W.-S.; Plutschack, M. B.; Berger, F.; Chabbra, S.; Schnegg, A.; Genicot, C.; Ritter, T. Nat. Chem. 2020, 12, 56; i) Ye, F.; Berger, F.; Jia, H.; Ford, J.; Wortman, A.; Börgel, J.; Genicot, C.; Ritter, T. Angew. Chem., Int. Ed. 2019, 58, 14615- 14619; j) Sang, R.; Korkis, S. E.; Su, W.; Ye, F.; Engl, P. S.; Berger, F.; Ritter, T. Angew. Chem., Int. Ed. 2019, 58, 16161-16166; k) Cowper, P.; Jin, Y.; Turton, M. D.; Kociok-Köhn, G.; Lewis, S. E. Angew. Chem., Int. Ed. 2016, 55, 2564- 2568.

13 a) Crivello, J. V. J. Polym. Sci., Part A: Polym. Chem. 1999, 37, 4241- 4254; b) Takahashi, Y.; Kodama, S.; Ishii, Y. Organometallics 2018, 37, 1649-1651; c) Yanez, C. O.; Andrade, C. D.; Belfield, K. D. Chem. Commun. 2009, 827-829.

14 a) Péter, Á.; Perry, G. J. P.; Procter, D. J. Adv. Synth. Catal. 2020, 362, 2135- 2142; b) Wang, X.; Truesdale, L.; Yu, J.-Q. J. Am. Chem. Soc. 2010, 132, 3648- 3649; c) Zhang, X.-G.; Dai, H.X.; Wasa, M.; Yu, J.-Q. J. Am. Chem. Soc. 2012, 134, 11948-11951; d) Zhang, L.-S.; Chen, K.; Chen, G.-H.; Li, B.-J.; Luo, S.; Guo, Q.-Y.; Wei, J.-B.; Shi, Z.-J. Org. Lett. 2013, 15, 10- 13.

15 a) Kim, Y.; Kim, M.; Gabbaï, F. P. Org. Lett. 2010, 12, 600- 602; b) Zhao, H.; Gabbai, G. Org. Lett. 2011, 13, 1444.; c) Tsao, F. A.; Waked, A. E.; Cao, L.; Hofmann, J.; Liu, L.; Grimme, S.; Stephan, D. W. Chem. Commun. 2016, 52, 12418- 12421.

16 a) Zhao, H.; Gabbaï, F. P. Nat. Chem. 2010, 2, 984- 990; b) Kim, Y.; Zhao, H.; Gabbaï, F. P. Angew. Chem., Int. Ed. 2009, 48, 4957- 4960 .

17 a) Adams, R. D.; Blankenship, C.; Segmueller, B. E.; Shiralian, M. J. Am. Chem. Soc. 1983, 105, 4319-4326; b) Adams, R. D.; Shiralian, M. Organometallics, 1982, 1, 883; c) Yoshida, T., Adachi, T., Sato, K., Baba K., Kanokogi, T. J. Chem. Soc., Chem. Commun. 1993,
1511-1513; d) Adams, R. D.; Chodosh, D. F. J. Organomet. Chem. 1976, 120, C39; e) Adams, R.D., Chodosh, D.F. J. Am. Chem. Soc. 1978, 100, 812-817.

18 a) Albrecht, M.; Van Koten, G. Angew. Chem., Int. Ed. 2001, 40, 3750- 3781; b) Peris, E.; Crabtree, R. H. Chem. Soc. Rev. 2018, 47, 1959- 1968

19 a) Tulchinsky, Y.; Iron, M. A.; Botoshansky, M.; Gandelman, M. Nitrenium ions as ligands for transition metals. Nat. Chem. 2011, 3, 525- 531; b) Tulchinsky, Y.; Kozuch, S.; Saha, P.; Botoshansky, M.; Shimon, L.; Gandelman, M. Chem. Sci. 2014, 5, 1305; c) Tulchinsky, Y.; Kozuch, S.; Saha, P.; Mauda, A.; Nisnevich, G.; Botoshansky, M.; Shimon, L. J. W.; Gandelman, M. Chem. - Eur. J. 2015, 21, 7099; d)Levy Vahav, H.; Pogoreltsev, A.; Tulchinsky, Y.; Fridman, N.; Börner, A.; Gandelman, M. Organometallics 2019, 38, 2494- 2501.

20 a) Huang, C.; Feng, J.; Ma, R.; Fang, S.; Lu, T.; Tang, W.; Du, D.; Gao, J. Org. Lett. 2019, 21, 9688- 9692; b) Yanez, C. O., Andrade, C. D. and Belfield, K. D. Chem. Commun. 2009, 827- 829.

${ }^{21}$ Searches were performed on the Cambridge Structural Database on September 2021

22 a) Kubas, G. J.; Ryan, R. R. Inorg. Chim. Acta 1981, 47, 131; b) R. R. Ryan, P. G. Eller, and G. J. Kubas, Inorg. Chem. 1976, 15, 4, 797799.

${ }^{23}$ Meij, R.; Stufkens, D. J.; Vrieze, K. J. Organomet. Chem. 1979, $164,353-370$.

24 a) Suess, D. L. M.; Peters, J. C. Organometallics 2012, 31, 5213- 5222; b) Fabio Meyer,Emanuel Hupf, Enno Lork, Simon Grabowsky, Stefan Mebs, Jens Beckmann, Eur. J. Inorg. Chem. 2020, 3829-3836.

25 Vigalok, A.; Shimon, L. J. W.; Milstein, D. J. Am. Chem. Soc. 1998, 120, 477- 483.

26 a) Ziegler, T.; Rauk, A. Inorg. Chem. 1979, 18, 1755, b) Ziegler, T.; Rauk, A. Theor. Chim. Acta 1977, 46, 1.

27 Mitoraj, M.; Michalak, A.; Ziegler, T. J. Chem. Theory Comput. 2009, 5, 962- 975.

28 a) Michalak, A.; Mitoraj, M.; Ziegler, T. J. Phys. Chem. A 2008, 112, 1933-1939; b) Mitoraj, M.; Michalak, A. Organome tallics 2007, 26,6576-6580; c) Mitoraj, M.; Michalak, A. J. Mol. Model. 2007, 13, 347-355; d) Mitoraj, M.; Michalak, A. J. Mol. Model. 2008, 14,681-687; e) Mitoraj, M. P.; Zhu, H.; Michalak, A.; Ziegler, T. Int. J. Quantum Chem. 2009, 109, 3379- 3386.

29 Lin, T.-P.; Gabbaï, F. P. Angew. Chem., Int. Ed. 2013, 52, 3864- 3868. 